\title{
The Role of Mediating Leadership Morality on the Influence of Organizational Culture on the Internal Control System
}

\author{
Lilis Marlina ${ }^{1, *}$, Arfriani Maifizar ${ }^{2}$, Ika Rahmadani ${ }^{1}$, Rina Maulina ${ }^{1}$, Linda \\ Rahmazaniati ${ }^{1}$, Tamitha Intassar Husen ${ }^{1}$, and Muhammad Zulkarnain ${ }^{3}$ \\ ${ }^{1}$ Lecturer in Accounting, Faculty of Economics, Universitas Teuku Umar, Indonesia \\ ${ }^{2}$ Lecturer in Sociology, Faculty of Social and Political Sciences, Universitas Teuku Umar, Indonesia \\ ${ }^{3}$ Sekolah Ting i Ilmu Manajemen Pasee, Indonesia \\ *Corresponding author email: arfrianimaifizar@utu.ac.id
}

\begin{abstract}
This research is aimed at analyzing the mediating role of leadership morality in the influence of organizational culture on the internal control sistem. The population in this research were all villages in West Aceh District, totaling 322 villages. The sampling method in this research using a purposive sampling method, for data collection techniques using a questionnaire. The data analysis method uses path analysis with SPPS software. The results of the research found that organizational culture has a direct effect on leadership morality. Meanwhile, leadership morality has a direct influence on the internal control sistem. The results of path analysis testing, organizational culture can directly or indirectly influence the internal control sistem. The results of this research prove that leadership morality can act as a mediating variable in the influence of organizational culture on the internal control sistem.
\end{abstract}

Keywords: Organizational Culture, Morality Leadership, Internal Control

\section{INTRODUCTION}

The government is one of the public sector organizations that is responsible for managing state finances. Good financial management can be achieved through the application of an internal control system. The Internal Control System is a policy and procedure designed to provide significant trust to management as evidence that the organization has achieved its goals and targets [1]. Internal Control System in government agencies is useful for preventing and minimizing fraud. The better the control and integrity system, the lower the tendency for fraud to be. If a company's internal control is weak, the possibility of errors and fraud is even greater [2].

\begin{abstract}
One of the fraudulent practices that still often occurs in Indonesia is corruption. ICW has monitored corruption in the village. The results of ICW's monitoring, in 2015 to 2017 cases of corruption in the village increased. In 2015, corruption cases reached 17 cases and increased to 41 cases in 2016. The jump more than doubled then occurred in 2017 with 96 cases. The total number of corruption cases found was 154 cases [3]. Furthermore, various modes of corruption were carried out by the actors of corruption in the village, including the practice of budget misuse of 51 cases, embezzlement of 32 cases, fictional reports with 17 cases, 15 cases of fictitious activities/projects, and budget inflation in 14 cases as shown in Figure 1.
\end{abstract}




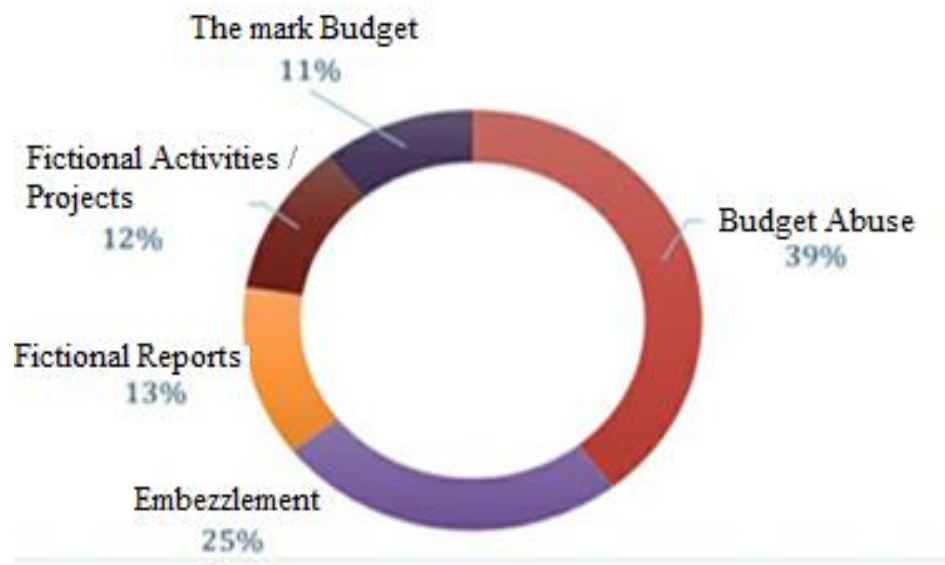

Figure 1. Corruption Mode in the Village Sector 2015-2017

Allegations of corruption in Gampong funds also occurred in West Aceh District. Serambi Indonesia released the news that the West Aceh District Attorney (Kejari) is still investigating a number of reports on the use of village funds that have been forwarded by the West Aceh Regency Government. In the report, there were 19 gampong suspected of having misappropriated Gampong funds from the audit of the West Aceh Inspectorate [4]. The high number of cases of misappropriation of gampong funds indicates that the internal control system of the gampong government is still weak, so efforts are needed to strengthen it. According to Robbin [5], the internal control system is closely related to organizational culture, culture functions as a sense maker and a control mechanism that provides guidance and forms of employee behavior and attitudes. New employees in the organization cannot immediately implement all the existing regulations, but these employees will see the habits or culture that exist in the organization. So that when the organizational culture is getting stronger, the implementation of the existing internal control system will be more effective. One of the main elements of internal control is the control environment. The control environment includes integrity, ethical values, leadership philosophy, operating style, etc. Establishing a control environment is synonymous with building an organizational culture [6].

The results of Zelmiyanti and Anita [7], research show that organizational culture has a significant positive effect on fraud prevention through the implementation of an internal control system. Ekayanti et al. [8] prove that there is a positive and significant influence between organizational culture on the effectiveness of the internal control system.

Cultural control is one indicator of the control environment. The culture developed by a company will influence the attitude of employees to comply with what is legalized and stay away from any restrictions. One way to develop an organizational culture is through religion. Religion has behavioral control for its adherents. If such control continues to be adhered to, it will become a religion-based culture [9]

Cultural development like this will be even stronger if there are organizational leaders who have good morals.
Leaders must have something that can influence others to achieve goals. Leaders are not only competent but also ethical in daily behavior [10].

According to Cornell et al. [11], governance leaders or bodies may be in a position to influence the extent to which strong internal control practices are applied in the church. Our research results show that some parties, especially financial experts who are on board of directors, have a positive impact on the level of internal control in the church.

This research uses a different model from previous studies. Previous research examined the effect of organizational culture and leadership morality directly on the internal control system with multiple linear regression models. In this model, organizational culture and leadership morality act as independent variables. Meanwhile, in this research, the model used is the path analysis. In this model, the organizational culture variable acts as an independent variable. Meanwhile, leadership morality acts as an intervening variable that mediates the indirect influence of organizational culture on the internal control system.

The formulation of the problems and objectives of this research are described as follows: (1) to analyze the influence of organizational culture directly on leadership morality, (2) to analyze the effect of leadership morality directly on the internal control system, (3) to analyze the influence of organizational culture directly and indirect to the internal control system through leadership morality, (4) to analyze the influence of organizational culture directly on the internal control system.

\section{LITERATURE REVIEW}

\subsection{Internal Control System Concept}

Internal control is a system designed to regulate an activity and is used as a guide in carrying out the operational activities of an organization. Organizations generally use an internal control system to control operational activities to prevent misuse of organizational resources [12]. 
According to the American Institute of Certified Public Accountants [13], internal control is defined as a process that is influenced by organizational structure, duties, authorities and responsibilities, employees, and management information systems, designed to help organizations achieve specific goals or objectives. On May 14, 2013, COSO published the Internal Control Integrated Framework (ICIF) as a revised version in 1992. The revision of the internal control framework is expected to help improve the implementation of internal control in every organization, although further adjustments are needed to harmonize internal control worldwide and to help organizations better manage risk and improve overall organizational performance [12]. According to COSO [14], internal control is a process carried out by the entity's board of directors, management and other personnel which is designed to provide reasonable assurance regarding the achievement of objectives related to operating activities, reporting and compliance.

Internal control systems are not new to Government and private sector organizations. Therefore, internal control must be implemented by ministers/institutional leaders, governors, regents/mayors in an integrated manner and become an integral part of government agency activities [15].

Furthermore, COSO issued 26 fundamental principles for the implementation of internal control. The 26 basic principles are connected to the five main components of the internal control system, including: (1) the control environment; (2) risk assessment; (3) control activities; (4) information and communication; and (5) monitoring [14].

\subsection{Organizational culture}

According to Luthans [16], organizational culture is the norms and values that contribute to the behavior of organizational members. Every member of the organization behaves in accordance with the prevailing culture so that members can mingle with the organizational environment. In line with that, Robbin [5] revealed that organizational culture is a shared value system held by organizational members so that it can differentiate one organization from another. According to Robbins [5], organizational culture is a descriptive and not evaluative concept, so measuring organizational culture is measuring how staff/personnel perceive their organization. Furthermore, Park et al. [31] explain that organizational culture can be defined as a common basic assumption that organizations learn while facing the environment and solving problems of external adaptation and internal integration which are taught to new members as the correct way to solve problems.

The virtue of organizational culture is the control and direction in shaping human attitudes and behavior who involve themselves in an organizational activity. Individuals and groups of individuals will not be separated from the organizational culture and in general they will be influenced by the diversity of existing resources as a stimulus for someone to act [30]. Therefore, in order for organizational culture to achieve its function, namely forming an organizational culture that has a positive impact on the organization, action is needed to prevent cultural dysfunction in the organization [6]. Wicaksono and Urumsah [10] emphasize that organizations instill a culture for employees to perform appropriate behavior within the organization.

\subsection{Leadership Morality}

Leadership is the ability of a person to lead a group of individuals to complete a certain mission, organize their staff with management objectives so that no defects in behavior are created [17]. Leadership is defined as, an effort to influence others to achieve organizational goals [18]. According to Jamil [17], leadership can be seen as a means to motivate and guide people in a planned way and direction in such a way that it becomes the main concern of the organization or leadership basically makes changes for organizational progress. Leaders not only have competent abilities but also behave ethically in everyday life [19]. Leaders also play an important role in determining the moral quality of a society and organization by influencing them negatively or positively [20].

Kanungo and Mendonca [21] view that morality and ethics are two interchangeable terms "what is ethical is moral, and what is moral is ethical". Ethical leadership is defined as demonstrating normative appropriate behavior through personal actions, interpersonal relationships, and promoting these behaviors to subordinates through twoway communication, reinforcement, and decision making. The first part of this definition shows normatively appropriate behavior (moral people) and the second part promotes this behavior to subordinates [22]. Ethical leadership has two dimensions: personal morals and managerial morals. Personal moral is normatively appropriate behavior that is manifested in honest, responsible and trustworthy behavior by others. Manager's morale means that leaders openly and explicitly talk about ethics and influence employee behavior and beliefs [23]-[24].

\section{METHODOLOGY}

The type of research used is explanatory research. Explanatory research explains the causal relationship of variables through hypothesis testing. This research used a quantitative approach by paying attention to phenomena and measuring the influence of organizational culture on the internal control system through leadership morality as an intervening variable.

The population in this research were all villages in West Aceh District, totaling 322 villages. The sampling method in this research used a purposive sampling method with the following criteria: the sub-district which has the largest population, the sub-district that is categorized as 
the center of government of West Aceh Regency, the gampong apparatus who occupies the position as keuchik, village secretary, general head of subdivision, and treasurer minimum work 1 year. Based on these criteria, Johan Pahlawan sub-district was selected as a sample with 4 gampong sets representing 21 gampongs, so that the sample size is 84 . The data in this research were collected using a questionnaire. The questionnaire was adopted and modified from [10], [25]-[27].

This research used three variables, namely the independent variable, the dependent variable, and the intervening variable. The independent variable in this research is organizational culture, while the dependent variable is the internal control system. The intervening variable used in this research is leadership morality. The operational definitions of each variable are as follows.

1) Organizational culture is the rules implied in the organization and how this culture influences and creates employees to conduct ethical behavior.

2) The internal control system is a process of actions and activities that are influenced by the leadership and all employees, which is designed to provide reasonable assurance regarding the achievement of objectives related to operating activities, reporting and compliance.

3) Leadership morality is the normatically appropriate leader's behavior which is manifested through actions and influencing employees to follow the norms in carrying out an action.

The data analysis used in this research is the path analysis model which is formulated through the following equation:

$M K=b_{1} B O+e_{1}$,

$S P I=b_{1} B O+b_{2} M K+e_{2}$,

where $M K$ is leadership morality, $B O$ is organizational culture, $S P I$ is internal control system.

\section{RESULTS AND DISCUSSION}

There were 84 questionnaires distributed to respondents in the keuchik office in Johan Pahlawan sub-district. Of these, 60 questionnaires were returned.

Based on the validity test using bivariate analysis for each questionnaire item consisting of 10 questions organizational culture, 7 questions leadership morality, and 27 questions of internal control system. All statements are valid, because $r$-count is greater than $r$ table (0.254). In the reliability test, the Cronbach's Alpha values for organizational culture, leadership morality, and internal control systems were $0.799,0.849$, and 0.940 . Nunnally and Pallant stated that any value of 0.70 and above would be acceptable for a good measure of internal consistency. While the results of the classical assumption test are summarized in Table 1 .

The results of the regression test on the equation model 1 as seen in Table 2, obtained the value of $t$-count $>t$-table $(3.738>1.671)$ with a significance value of $0.000<0.05$. This proves that organizational culture has a direct influence on leadership morality. The regression coefficient value of the organizational culture variable was 0.441. This value shows that the stronger the organizational culture, the stronger the leadership morality. Positive organizational culture is in line with ethical leadership [22]. Therefore, the most important values that shape organizational culture are those that refer to ethics or morals [28].

Furthermore, in the results of the regression test using the equation model 2 to analyze the effect of leadership morality directly on the internal control system, the tvalue > t-table $(7.107>1.671)$ was obtained with a significance value of $0.000<0.05$ and the regression coefficient of 0.561 . This shows that leadership morality has a direct influence on the internal control system. The results of this research are in accordance with the results of research [29].

Table 1. Classical assumption test results

\begin{tabular}{|c|c|c|c|}
\hline No. & Classic assumption test & Model (Analysis Tool) & Values and Decisions \\
\hline 1. & Normality test & Kolmogorov-Smirnov (K-S) & $\begin{array}{l}\text { Asymp.Sig. KS equal to } 0.200 \text {, the value is } \\
\text { greater than } 0.05 \text {. } \\
\text { Decision: normally distributed data }\end{array}$ \\
\hline 2. & Multicollinearity Test & Variance Inflation Factor (VIF) & $\begin{array}{l}\text { VIF: } \mathrm{BO}=1.241, \mathrm{LM}=1.241 . \\
\text { Decision: VIF } \mathrm{BO} \text { and } \mathrm{LM} \text { values are less than } \\
10 \text {, so there is no multicollinearity. }\end{array}$ \\
\hline 3. & Autocorrelation Test & Durbin Watson (DW) & $\begin{array}{l}\text { DW: } 1.969 \\
\text { Decision: because the value is between } 1.72 \text { and } \\
2.27 \text {, so there is no autocorrelation. }\end{array}$ \\
\hline 4. & Heteroscedasticity Test & Glejser test & $\begin{array}{l}\text { Absolute residual regression results: } \mathrm{BO} \text { with } \\
\text { Sig. equal to } 0.403 \text {, and LM with Sig. equal to } \\
0.150 \text {. } \\
\text { Decision: because the Sig. for each variable less } \\
\text { than } 0.05 \text {, so heteroscedasticity does not occur. }\end{array}$ \\
\hline
\end{tabular}


Table 2. Test Results of Organizational Culture Influence on Leadership Morality

\begin{tabular}{|c|c|c|c|c|c|c|}
\hline & \multirow[t]{2}{*}{ Model } & \multicolumn{2}{|c|}{ Unstandardized Coefficients } & \multirow{2}{*}{$\frac{\text { Standardized Coefficients }}{\text { Beta }}$} & \multirow[t]{2}{*}{$\mathrm{t}$-count } & \multirow[t]{2}{*}{ Sig. } \\
\hline & & $\mathrm{B}$ & Std. Error & & & \\
\hline \multirow[t]{2}{*}{1} & (Constant) & 17.917 & 3.380 & & 5.301 & .000 \\
\hline & $\mathrm{BO}$ & .308 & .082 & .441 & 3.738 & .000 \\
\hline
\end{tabular}

a. Dependent Variable: MK

Table 3. Test Results of the Influence of Organizational Culture and Leadership Morality on the Internal Control System

\begin{tabular}{|c|c|c|c|c|c|c|}
\hline & \multirow[t]{2}{*}{ Model } & \multicolumn{2}{|c|}{ Unstandardized Coefficients } & Standardized Coefficients & \multirow[t]{2}{*}{$\mathrm{t}$ count } & \multirow[t]{2}{*}{ Sig. } \\
\hline & & $\mathrm{B}$ & Std. Error & Beta & & \\
\hline \multirow[t]{3}{*}{1} & (Constant) & 24.496 & 7.539 & & 3.249 & .002 \\
\hline & $\mathrm{BO}$ & .914 & .168 & .430 & 5.447 & .000 \\
\hline & MK & 1.709 & .240 & .561 & 7.107 & .000 \\
\hline
\end{tabular}

a. Dependent Variable: SPI

As for proving the influence of organizational culture, either directly or indirectly, on the internal control system through leadership morality as an intervening variable, the results can be obtained through path analysis obtained from equation model 1 and 2 . The following is a figure of the path analysis of the variables. Each variable contained in the research model. The results of path analysis using SPPS for each equation (model 1) can be seen in the Table 2.

Based on the results of path analysis, organizational culture has a direct influence on the internal control system with a value of $t$-count $>t$-table $(5.477>1.671)$ or Sig. $0.000<0.05$. The regression coefficient for organizational culture in the path analysis model referred to as $\mathrm{P} 1$ is 0.430 . As for the indirect influence of organizational culture on the internal control system through leadership morality, it can be calculated in the following ways.

Direct effect of BO to SPI $=\mathrm{P} 1$.

The indirect effect of $\mathrm{BO}$ to $\mathrm{MK}$ to $\mathrm{SPI}=\mathrm{P} 2 \times \mathrm{P} 3$.

Total indirect effect of $\mathrm{BO}$ to $\mathrm{SPI}=\mathrm{P} 1+(\mathrm{P} 2 \times \mathrm{P} 3)$.

Based on the results of these calculations, the total effect is $0.677(0.431+(0.441 \times 0.561))$. Since the total indirect effect $>$ direct effect is $0.677>0.431$, it can be concluded that the actual relationship is indirect. This proves that leadership morality can mediate the influence of organizational culture on the internal control system. The results of this research support the research results of Puspasari and Suwardi [29], which show that there is an interaction between the moral level of public sector managers and internal control. The results of path analysis using SPPS for each equation (model 2) can be seen in the Table 3 .

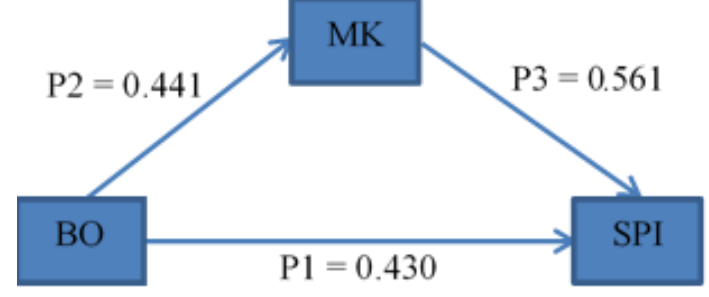

Figure 2. Path Analysis Results

In addition, ethical leadership can bring beneficial consequences for employees and organizations that are reflected in perceived leader effectiveness, employee job satisfaction, increased dedication and problem reporting [24]. This leadership moral can form a positive organizational culture in accordance with prevailing norms so that it can strengthen the internal control system to achieve organizational goals and the reliability of financial reports by complying with applicable principles.

\section{CONCLUSION}

Based on the research results, it can be concluded that organizational culture has a direct effect on leadership morality. Meanwhile, leadership morality has a direct influence on the internal control system. This research also found that organizational culture can directly or indirectly influence the internal control system. These results prove that leadership morality can act as a mediating variable on the influence of organizational culture on the internal control system. Thus, to increase the strengthening of internal control systems, organizational leaders should make maximum efforts to form a good organizational culture and through good moral exemplary from a leader, internal control. 


\section{REFERENCES}

[1] R. I. G. Agung, Audit Kinerja Pada Sektor Publik. Jakarta: Grafindo, 2010.

[2] K. Y. K. Dewi, N. M. D. Ratnadi, Pengaruh Pengendalian Internal dan Integritas pada Kecenderungan Kecurangan Akuntansi Satuan Kerja Perangkat Daerah Kota Denpasar. E-Jurnal Akuntansi, 18 (2) (2017), 917-941.

[3] ICW, Outlook Dana Gampong 2018 Potensi Penyalahgunaan Anggaran Gampong di Tahun Politik, 2018.

[4] Serambinews.com, Jaksa Usut Ttemuan Penyimpangan Dana Desa, 2019.

[5] S. P. Robbin, Prinsip-Prinsip Prilaku Organisasi, Edisi Kelima. Jakarta: Erlangga, 2002.

[6] N. Hamidi, E. Suwardi, Analisis akuntabilitas publik organisasi pengelola zakat berdasarkan aspek pengendalian intern dan budaya organisasi (survei pada organisasi pengelola zakat di Indonesia). Ekbisi, 8 (1) (2013).

[7] R. Zelmiyanti, L. Anita, Pengaruh Budaya Organisasi dan Peran Auditor Internal Terhadap Pencagahan Kecurangan dengan Pelaksanaan Sistem Pengendalian Internal Sebagai Variabel Intervening. Jurnal Akuntansi Keuangan dan Bisnis, 8 (2015), 6776.

[8] N. W. Ekayanti, S. E. Edy Sujana, M. A. Wahyuni, Pengaruh Budaya Organisasi, Gaya Kepemimpinan dan Pengalaman Kerja Terhadap Efektivitas Sistem Pengendalian Intern Pada Lembaga Perkreditan Desa (LPD) Se-Kecamatan Payangan Kabupaten Gianyar. JIMAT (Jurnal Ilmiah Mahasiswa Akuntansi) Undiksha, 7 (1) (2017).

[9] H. Mukhibad, Maintaining Employees' Morality to Improve Internal Control in the Sharia Microfinance Institution. Walisongo: Jurnal Penelitian Sosial Keagamaan, 25 (2) (2017), 507-528.

[10] A. P. Wicaksono, D. Urumsah, Factors influencing employees to commit fraud in workplace empirical study in Indonesian hospitals. Asia Pacific Fraud Journal, 1 (1) (2017), 1-18.

[11] R. M. Cornell, C. B. Johnson, W. C. Schwartz, Influence of leadership positions on internal controls and reported fraud in religious organizations. Journal of Forensic \& Investigative Accounting, 5 (1) (2013), 85125.
[12] R. D. Yuniarti, The effect of internal control and anti-fraud awareness on fraud prevention (A survey on inter-governmental organizations). Journal of Economics, Business \& Accountancy Ventura, 20 (1) (2017), 113-124.

[13] American Institute of Certified Public Accountants (AICPA), Consideration of Fraud in Financial Statement Audit. Statement on Auditing Standards No. 82. New York, 2003.

[14] COSO, Internal Control-Integrated Framework, 2013.

[15] K. F. Dewi, A. Widana Putra, I. B. P. Astika Pengaruh Budaya Organisasi, Pengendalian Internal dan Kejelasan Sasaran Anggaran Pada Akuntabilitas Kinerja SKPD Kabupaten Gianyar dengan Komitmen Organisasi Sebagai Variabel Moderasi. Jurnal Buletin Studi Ekonomi, 22 (1) (2017).

[16] F. Luthans, Perilaku Organisasi, Edisi Kesepuluh. Yogyakarta: Penerbit Andi, 2006

[17] M. Y. Jamil, Islamic Perspective of Leadership: A Role Model for Today's CEOs. Journal of Islamic Thought and Civilization, 5 (2) (2015), 24-45.

[18] S. Tubbs, E. Schulz, Exploring a taxonomy of global leadership competencies and meta-competencies. The Journal of American Academy of Business, 8 (2) (2006), 29-35.

[19] J. B. Cuilla, Leadership ethics: Mapping the territory. Business Ethics Quarterly, 5 (1) (1995), 5-28.

[20] M. Yasir, N. A. Mohamad, Ethics and morality: Comparing ethical leadership with servant, authentic and transformational leadership styles. International Review of Management and Marketing, 6 (4) (2016), 310-316

[21] R. N. Kanungo, M. Mendonca, Ethical dimensions of leadership. Sage Publications, 1996.

[22] SuR. Toor, G. Ofori, Ethical Leadership: Examining the Relationships with Full Range Leadership Model, Employee Outcomes, and Organizational Culture. J Bus Ethics 90 (533) (2009).

[23] L. K. Trevino, L. P. Hartman, M. Brown, Moral person and moral manager: How executives develop a reputation for ethical leadership. California management review, 42 (4) (2000), 128-142.

[24] M. E. Brown, L. K. Treviño, D. A. Harrison, Ethical leadership: A social learning perspective for construct development and testing. Organizational 
Behavior and Human Decision Processes, 97 (2) (2005), 117-134.

[25] R. Fehr, K. C. Yam, C. Dang, Moralized leadership: The construction and consequences of ethical leader perceptions. Academy of Management Review, 40 (2) (2015), 182-209.

[26] M. S. A. Alharbi, The effectiveness of The Implementation of Internal Control in Kuwaiti Shareholding Companies. International Journal of Academic Research in Accounting, Finance and Management Sciences, 7 (4) (2017), 232-241.

[27] M. Ahmed, S. Shafiq, The impact of organizational culture on organizational performance: a case study on telecom sector. Global journal of management and business research, 14 (3) (2014).

[28] K. K. Mihelic, B. Lipicnik, M. Tekavcic, Ethical leadership. International Journal of Management \& Information Sistems (IJMIS), 14 (5) (2010).

[29] N. Puspasari, E. Suwardi, The effect of individual morality and internal control on the propensity to commit fraud: Evidence from local governments. Journal of Indonesian Economy and Business, 31 (2) (2016), 208-219.

[30] H. T. Koesmono, Pengaruh budaya organisasi terhadap motivasi dan kepuasan kerja serta kinerja karyawan pada sub sektor industri pengolahan kayu skala menengah di Jawa Timur. Jurnal Manajemen dan Kewirausahaan, 7 (2) (2005), 171-188.

[31] H. Park, V. Ribière, W. D. Schulte, Critical attributes of organizational culture that promote knowledge management technology implementation success. Journal of Knowledge Management, 8 (3) (2014), 106-117. 